\title{
Glocal, Holistic and Performative Education
}

\author{
Professor Ph.D. Emina Berbic Kolar ${ }^{1}$, Ph.D. Vesna Srnic ${ }^{2}$ \\ ${ }^{1}$ Professor Ph.D. Emina Berbic Kolar, Vice Dean, J.J. Strossmayer University of Osijek, Faculty \\ of Education in Osijek, The Republic of Croatia \\ ${ }^{2}$ Ph.D. Vesna Srnic, Research Fellow, J.J. Strossmayer University of Osijek, Faculty of \\ Education in Osijek, Department in Slavonski Brod, The Republic of Croatia
}

\begin{abstract}
We look at innovative education through a global and local approach to the philosophy of existence, known as glocalization, and through the psychological Gestalt of experiencing a whole that is inevitably viewed within social science by a sociological holistic principle. Our glocal, holistic, aesthetic practice has been experienced and realized through intensive performative education that enhances the existential capacity in multi / media projects through the humanistic approach, affectively using digital framing. Performative projects are performed in the Media Culture course at the Faculty of Teacher Education in Osijek, Department in Slavonski Brod (FOOZOS), including vertical education of primary and secondary students. The education process is performed through lectures, intensified through e-learning, and finalized by group orchestration in a large project supported by the non-profit organization Culture, Media and Education - Arthea and the Ministry of Culture of the Republic of Croatia. Examples of successfully implemented glocal, holistic and performative education can be seen in the videos: Baroque in Postmodern Glocal Approach, (created for the European Schoolnet Academy, 2019), Situationally Performative Smartphone Orchestra (conducted performance, Slavonski Brod town square, 2018), Post-Modern Dystopic Deconstruction for Mobile Phones Orchestra (FOOZOS, Department in Slavonski Brod, 2017), Project with Mobile phones (mobile learning for the course Contemporary Media in Literature Lectures, FOOZOS, Department in Slavonski Brod, 2016), multimedia poem The Soul of the World (Music Biennale Zagreb, 2007) and New Education Model: Multimedia Art (Christmas in Musical Pictures, 2004, Concert Hall, Slavonski Brod).
\end{abstract}

Keywords: aesthetics; digital-embodiment; performance-art; school-for-life-reform; unbreakable-multimedia-narrative 